九州大学学術情報リポジトリ

Kyushu University Institutional Repository

\title{
Johannsenite from Teragōchi, Okayama Prefecture, Japan
}

Momoi, Hitoshi

Faculty of Science, Kyushu University

https://doi.org/10.5109/1543612

出版情報：九州大學理學部紀要：Series D, Geology. 15 (1)，pp.65-72, 1964-06-25. Faculty of Science, Kyushu University バージョン：

権利関係 : 
Mem. Fac. Sci., Kyushu Univ., Ser. D, Geology, Vol. XV, No. 1, pp. $65-72,2$ text-figs, 5 tables, plate 6 . May 31,1964

\title{
Johannsenite from Teragōchi, Okayama Prefecture, Japan
}

\section{By}

\author{
Hitoshi MOMOI
}

\begin{abstract}
A new occurence of johannsenite has been found in manganese ore deposits at Teragōchi, Okayama Prefecture, Japan. The mineral occurs as a chief component of the massive manganess ore. Aggregates of bluish johannsenite crystals look quite similar to those of skarn hedenbergite. It has following chemical composition: $\mathrm{SiO}_{2}$ 48.02, $\mathrm{TiO}_{2}$ tr., $\mathrm{Al}_{2} \mathrm{O}_{3}$ 0.80, $\mathrm{Fe}_{2} \mathrm{O}_{3}$ 0.30, $\mathrm{FeO} 3.20, \mathrm{MnO} 27.53, \mathrm{MgO} 0.48, \mathrm{CaO}$ 19.10, $\mathrm{Na}_{2} \mathrm{O} 0.25, \mathrm{~K}_{2} \mathrm{O} 0.04, \mathrm{H}_{2} \mathrm{O}^{+} 0.23, \mathrm{H}_{2} \mathrm{O}^{-} 0.00$, total 99.95 wt. \%. Silky green variety with following composition was also found: $\mathrm{SiO}_{2} 48.18, \mathrm{Al}_{2} \mathrm{O}_{3} 0.80, \mathrm{Fe}_{2} \mathrm{O}_{3} 1.00, \mathrm{FeO}$ 4.82, $\mathrm{MnO} 26.29, \mathrm{MgO} 0.47, \mathrm{CaO} 18.79, \mathrm{Na}_{2} \mathrm{O} 0.20, \mathrm{~K}_{2} \mathrm{O} 0.04, \mathrm{H}_{2} \mathrm{O}^{+} 0.10, \mathrm{H}_{2} \mathrm{O}^{-} 0.00$, total $100.69 \mathrm{wt} . \%$. Optical properties for the blue johannsenite: $\alpha=1.707, \beta=1.720$, $\gamma=1.736, \gamma-\alpha=0.029,2 \mathrm{~V}(\dot{+}) 72^{\circ}$. Sp. gr. (blue variety) $=3.54\left(21^{\circ} \mathrm{C}\right)$. Unit cell dimensions obtained by X-ray powder method are: (blue variety) $a_{0}=9.91_{6} \AA, b_{0}=9.10_{\text {r }}$ $\AA, c_{0}=5.28_{0} \AA, \beta=74^{\circ} 49^{\prime}$ : (green variety) $a_{0}=9.91_{3} \AA, b_{0}=9.10_{4} \AA, c_{0}=5.27_{4} \AA, \beta=$ $74^{\circ} 48^{\prime}$. Powder data and infrared spectra are also presented together with the heating effect of johannsenite.
\end{abstract}

\section{Introduction}

Occurrences of johannsenite have been recorded from Italy, Mexico, Australia (Broken Hill), New Jersey (Franklin Furnace), New Mexico, and Oregon. Professor Yoshimura adviced me to study a specimen looking like hedenbergite labelled as from "the Ōnagusa mine, Okayama Prefecture" in the $\mathrm{K} \overline{\mathrm{O}}$ collection of Kyushu University (YoshimuRA, 1952, P. 103). In 1959, I visited a manganese mine at Teragōchi, $1 \mathrm{~km}$. northwest of the Nagusa copper mine, Katsuyama town, Maniwa Country, Okayama Prefecture*, and found there a mineral looking similar to the specimen of the $\mathrm{K} \overline{\mathrm{O}}$ collection, in some piles of manganese ores. At that time, the deposits had not been working. The locality is shown in Figure 1. The specimen was identified as johannsenite by chemical analyses, X-ray powder method, optical properties, and infrared absorption. This paper is a mineralogical description of the johannsenite, found for the first time in Japan.

The manganese ore deposits are developed in siliceous limestone and in green phyllite belonging to the Permian limestone beds and the Sangun metamorphic rocks (YAMADA, 1941: MitsuNo, 1963). It was unable for me to observe the mode of occurrence of johannsenite in situ because of the abandoned mine. Only one massive outcrop, bearing johannsenite was recognized,

Manuscript received October 31, 1963.

* 岡山県真庭郡勝山町寺河内 


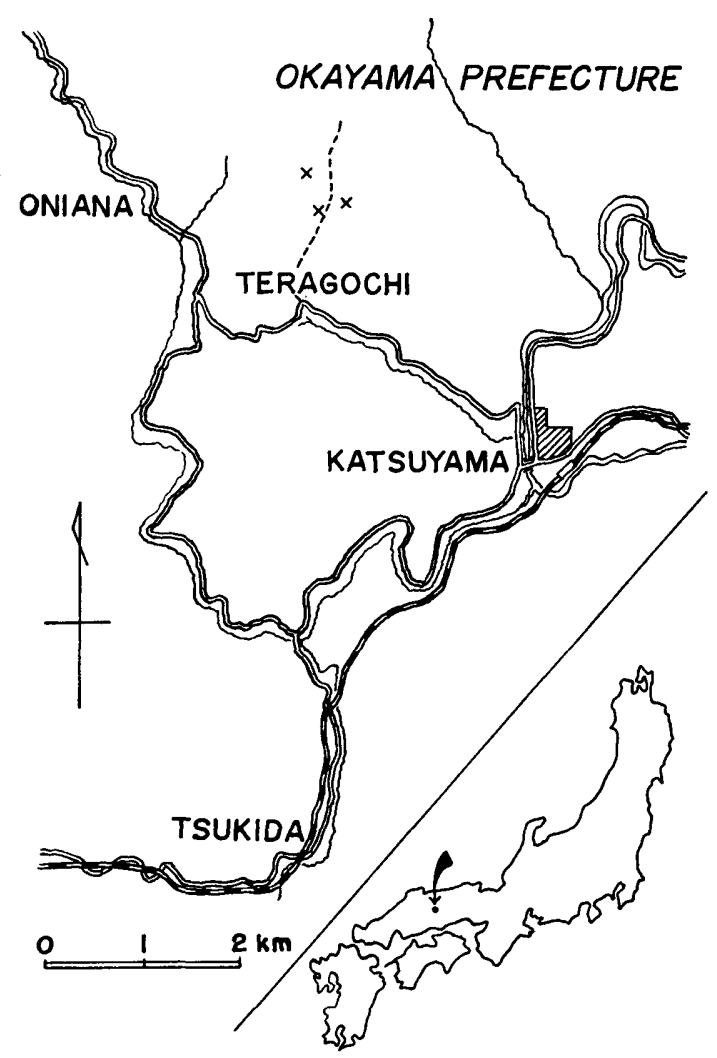

Fig. 1. Location of the manganese ore deposits bearing johannsenite $(X)$ at Teragōchi, Okayama Prefecture, Japan.

being heavily contaminated with manganese dioxide. This ore body has a strike of $\mathrm{N} 60^{\circ} \mathrm{W}$, and a dip of $\mathrm{NE} 70^{\circ}$, which are near the general trend of the wall rocks, and is composed of johannsenite, manganese oxides, rhodonite, quartz, calcite, galena, and sphalerite.

The main portion of johannsenite is seen fully altered to manganese dioxide, (todorokite with low crystallinity) and to powdery opaline silica. The oxide ore has fibrous radial texture pseudomorphous after johannsenite. Tiny rhodonite crystal are seen around a quartz vein which traverses the johannsenite aggregate. Simultaneous crystallization of calcite and sulphides are observed among rhodonite crystals. Quartz veins are also seen accompanied by a small amount of galena and sphalerite. Bustamite and wollastonite were not found in the johannsenite deposits.

\section{Physical properties}

Large johannsenite crystals are up to $15 \mathrm{~cm}$. in length, and $5 \mathrm{~mm}$. in width, and show long columner or fibrous texture. Radial or parallel growth 
is common. Color is light cobalt blue, bluish green or dark green with resinous to silky luster. Bluish crystal, surrounded zonally by greenish one, appears very similar to that of hedenbergite. Specific gravity and optical properties were measured on a bluish crystal. Specific gravity; is 3.54 at $21^{\circ} \mathrm{C}$ (pycnometer method). Optical properties: $\alpha=1.707, \beta=1.720, \gamma=1.736, \gamma-\alpha=0.029$, $2 \mathrm{~V}(+) 72^{\circ}, \mathrm{b}=\mathrm{Y}$, twinning plane (100), $\mathrm{C} \frown \mathrm{Z}=55^{\circ}$.

\section{Chemical composition}

Chemical analyses of blue and green johannsenites were made on pure materials prepared by hand picking. The flame photometric method was adopted for alkalies, and the common gravimetric mehtod for the other metal oxides. The results are given in Table 1, together with some other previous data. Atomic ratios were calculated on the basis of six oxygens with the following results;

Blue variety $\left(\mathrm{Na}_{0.02} \mathrm{Mg}_{0.03} \mathrm{Ca}_{0.85}\right)_{0.90}\left(\mathrm{Mn}_{0.96} \mathrm{Fe}^{\prime \prime}{ }_{0.11} \mathrm{Fe}^{\prime \prime \prime}{ }_{0.01} \mathrm{Al}_{0.02}\right)_{1.10}\left(\mathrm{Al}_{0.02} \mathrm{Si}_{1.98}\right)_{2.00} \mathrm{O}_{6.00}$ Green variety $\left(\mathrm{Na}_{0.02} \mathrm{Mg}_{0.03} \mathrm{Ca}_{0.83}\right)_{0.88}\left(\mathrm{Mn}_{0.91} \mathrm{Fe}^{\prime \prime}{ }_{0.17} \mathrm{Fe}^{\prime \prime \prime}{ }_{0.03} \mathrm{Al}_{0.02}\right)_{1.13}\left(\mathrm{Al}_{0.02} \mathrm{Si}_{1.98}\right)_{2.00} \mathrm{O}_{6.00}$ Both results are very close to the ideal formula of johannsenite, $\mathrm{CaMnSi}_{2} \mathrm{O}_{6}$. Difference of color between the two varieties may probably be due to their iron contents.

Table 1. Chemical compositions of johannsenites

\begin{tabular}{|c|c|c|c|c|}
\hline Locality & $\begin{array}{c}\text { Broken Hill } \\
\text { Australia }\end{array}$ & $\begin{array}{l}\text { Mt. Civillina } \\
\text { Italy }\end{array}$ & \multicolumn{2}{|c|}{$\begin{array}{c}\text { Teragōchi* } \\
\text { Japan }\end{array}$} \\
\hline Reference & $\begin{array}{c}\text { HuTTON } \\
1956\end{array}$ & $\begin{array}{c}\text { Schiavinato } \\
1953\end{array}$ & \multicolumn{2}{|c|}{ This paper } \\
\hline Color & Pale green & - & Light blue & Silky green \\
\hline $\mathrm{SiO}_{2}$ & 48.39 & 47.90 & 48.02 & 48.18 \\
\hline $\mathrm{TiO}_{2}$ & nil. & tr. & tr. & - \\
\hline $\mathrm{Al}_{2} \mathrm{O}_{3}$ & 0.58 & tr. & 0.80 & 0.80 \\
\hline $\mathrm{Fe}_{2} \mathrm{O}_{3}$ & nil? & 0.25 & 0.30 & 1.00 \\
\hline $\mathrm{FeO}$ & 13.44 & 0.98 & 3.20 & 4.82 \\
\hline $\mathrm{MnO}$ & 14.14 & 26.81 & 57.53 & 26.29 \\
\hline $\mathrm{MgO}$ & 2.19 & 0.96 & 0.48 & 0.47 \\
\hline $\mathrm{CaO}$ & 20.79 & 21.62 & 19.10 & 18.79 \\
\hline $\mathrm{Na}_{2} \mathrm{O}$ & 0.05 & - & 0.25 & 0.20 \\
\hline $\mathrm{K}_{2} \mathrm{O}$ & 0.09 & - & 0.04 & 0.04 \\
\hline $\mathrm{H}_{2} \mathrm{O}^{+}$ & 0.08 & 0.26 & 0.23 & 0.10 \\
\hline $\mathrm{H}_{2} \mathrm{O}^{-}$ & 0.12 & 0.50 & 0.00 & 0.00 \\
\hline $\mathrm{CO}_{2}$ & - & 1.11 & - & - \\
\hline Total & 99.87 & 100.39 & 99.95 & 100.69 \\
\hline
\end{tabular}

\footnotetext{
* Analyst: H. MoмoI
} 


\section{X-ray powder study}

X-ray powder patterns were obtained by a Shimadzu X-ray diffractometer with filtered $\mathrm{Fe} \mathrm{K} a$ radiation. The experimental conditions were: $30 \mathrm{KV}$, $10 \mathrm{~mA}$, full scale 500 counts per second, time constant 2.5 or 5.0 seconds, scanning speed 2 or $\frac{1}{4}$ degrees per minute, slits $3-2-0.4 \mathrm{~mm}$. The readings of diffraction angles were corrected with an internal standard of silicon. The unit cell dimensions were determined from the following reflections: $(600)$, $(060),(350),(53 \overline{1})$, and (750). The indexing was made in referring to those of clinopyroxene by KUNO and Hess (1953) and by YAMAGUCHI (1961). The results are listed in Tables 2 and 3 . The observed and calculated d-values are in good agreement. The unit cell dimensions of the Thragōchi johannsenites

Table 2. X-ray powder data for johannsenite (blue) from Teragöchi, Okayama Prefecture, Japan

(Fe $\mathrm{K} \alpha$ filtered with $\mathrm{Mn}, \lambda=1.9373 \AA$ )

\begin{tabular}{|c|c|c|c|c|}
\hline I & $2 \theta$ & dobs. $(\AA)$ & dealc. $(\AA)$ & hkl \\
\hline $\begin{array}{r}14 \\
9 \\
5 \\
33\end{array}$ & $\begin{array}{l}16.90 \\
23.39 \\
24.57 \\
34.15\end{array}$ & $\begin{array}{l}6.592 \\
4.779 \\
4.553 \\
3.229\end{array}$ & $\begin{array}{l}6.595 \\
4.782 \\
4.553 \\
3.298\end{array}$ & $\begin{array}{l}110 \\
200 \\
020 \\
220\end{array}$ \\
\hline 100 & 37.41 & 3.020 & $\left\{\begin{array}{l}3.031 \\
3.009\end{array}\right.$ & $\begin{array}{l}221 \\
310\end{array}$ \\
\hline $\begin{array}{r}16 \\
20 \\
31 \\
25 \\
6 \\
10\end{array}$ & $\begin{array}{l}38.68 \\
43.66 \\
44.40 \\
44.70 \\
47.82 \\
48.72\end{array}$ & $\begin{array}{l}2.925 \\
2.605 \\
2.564 \\
2.547 \\
2.390 \\
2.348\end{array}$ & $\begin{array}{l}2.930 \\
2.607 \\
2.563 \\
2.546 \\
2.391 \\
2.347\end{array}$ & $\begin{array}{l}311 \\
131 \\
221 \\
002 \\
400 \\
311\end{array}$ \\
\hline $8 B$ & 51.24 & 2.240 & $\left\{\begin{array}{l}2.238 \\
2.242\end{array}\right.$ & $\begin{array}{l}312 \\
112\end{array}$ \\
\hline $\begin{array}{l}11 \\
17\end{array}$ & $\begin{array}{l}52.28 \\
53.12\end{array}$ & $\begin{array}{l}2.1986 \\
2.1664\end{array}$ & $\begin{array}{l}2.1984 \\
2.1671\end{array}$ & $\begin{array}{l}330 \\
331\end{array}$ \\
\hline $\begin{array}{r}12 \\
4\end{array}$ & 53.88 & 2.1380 & 2.1401 & $\begin{array}{l}421 \\
420\end{array}$ \\
\hline $\begin{array}{l}4 \\
6\end{array}$ & $\begin{array}{l}54.45 \\
55.53\end{array}$ & $\begin{array}{l}2.1170 \\
2.0794\end{array}$ & $\begin{array}{l}2.1169 \\
2.0784\end{array}$ & $\begin{array}{l}420 \\
041\end{array}$ \\
\hline $2 \mathrm{w}$ & 56.8 & 2.037 & 2.0345 & $20 \overline{2}$ \\
\hline 11 & 57.03 & 2.0290 & 2.0311 & 402 \\
\hline 2 & 58.20 & 1.9917 & 1.9919 & 132 \\
\hline $2 w$ & 61.4 & 1.897 & 1.8965 & 331 \\
\hline $\begin{array}{l}6 \\
2 \mathrm{w}\end{array}$ & & $\begin{array}{l}1.8715 \\
1.812\end{array}$ & $\begin{array}{l}1.3720 \\
1.8104\end{array}$ & $\begin{array}{l}510 \\
421\end{array}$ \\
\hline 15 & 65.51 & 1.7904 & 1.7892 & 150 \\
\hline $2 w$ & 69.6 & 1.697 & 1.6971 & 042 \\
\hline $17 \mathrm{~B}$ & 71.87 & 1.6505 & $\left\{\begin{array}{l}1.6488 \\
1.6526\end{array}\right.$ & $\begin{array}{l}440 \\
531\end{array}$ \\
\hline 12 & 72.60 & 1.6362 & 1.6352 & 223 \\
\hline $2 w$ & 73.5 & 1.619 & 1.618 & 530 \\
\hline 9 & 74.845 & 1.5940 & 1.5940 & 600 \\
\hline - & -7 & $\overline{-17}$ & 1.5904 & 023 \\
\hline 6 & 75.53 & 1.5817 & 1.5815 & 350 \\
\hline $5 B$ & 77.28 & 1.5484 & $\left\{\begin{array}{l}1.5518 \\
1.5474\end{array}\right.$ & $\begin{array}{l}621 \\
602\end{array}$ \\
\hline 12 & 79.310 & 1.5178 & 1.5178 & 060 \\
\hline $\overrightarrow{12}$ & $82-$ & $\overline{1515}$ & 1.5156 & 442 \\
\hline 12 & 83.722 & 1.4515 & 1.4515 & $53 i$ \\
\hline 6 & 85.275 & 1.4300 & 1.4300 & 352 \\
\hline
\end{tabular}

B: broad, w: weak. 
Table 3. Unit cell dimensions of johannsenites

\begin{tabular}{c|c|c|c|c|c}
\hline Locality & Reference & $\mathrm{a}_{0}(\AA)$ & $\mathrm{b}_{0}(\AA)$ & $\mathrm{c}_{0}(\AA)$ & $\beta$ \\
\hline $\begin{array}{c}\text { Teragōehi } \\
\text { Japan }\end{array}$ & $\begin{array}{c}\text { This paper } \\
\text { (Blue) }\end{array}$ & 9.916 & 9.107 & 5.280 & $74^{\circ} 49^{\prime}$ \\
$\begin{array}{c}\text { Ditto. } \\
\text { Civillina } \\
\text { Italy }\end{array}$ & $\begin{array}{c}\text { ScHravinato } \\
1953\end{array}$ & 9.913 & 9.104 & 5.279 & $74^{\circ} 48^{\prime}$ \\
$\begin{array}{c}\text { Herault } \\
\text { California } \\
\text { (Hedenbergite) }\end{array}$ & $\begin{array}{c}\text { KuNo and } \\
\text { Hess } \\
1953\end{array}$ & 9.81 & 9.02 & 5.26 & $75^{\circ}$ \\
\hline
\end{tabular}

are somewhat larger than those of an Italian specimen (Schiavinato, 1953). The calculated densities are $3.56_{9}$ (blue) and $3.57_{9}$ (green).

\section{Infrared absorption spectra}

The infrared absorpiton spectra of blue johannsenite were obtained with a Hitachi double beam infrared spectrometer using $\mathrm{KBr}$ disks. The results are shown in Table 4 and Figure 2. The absorptions by $\mathrm{CO}_{2}$ and $\mathrm{H}_{2} \mathrm{O}$ are excluded because they were probably contaminated in air. The spectra of hedenbergite (FeO 18.75 wt.\%) from the Mitate mine, Miyazaki Prefecture are also shown in the same table and figure for comparison's sake. It is clear that both minerals have very close resemblances in absorption. The absorptions of johannsenite are observed at the slightly longer sides in wave length than those of hedenbergite owing to the absorption differences between ferrous iron in hedenbergite and divalent manganese in johannsenite.

Table 4. Infrared absorption spectra of johannsenite, its heating product, and related minerals

\begin{tabular}{|c|c|c|c|c|c|c|c|}
\hline \multirow{2}{*}{\multicolumn{2}{|c|}{$\begin{array}{l}\text { Hedenbergite } \\
\text { Mitate mine }\end{array}$}} & \multicolumn{2}{|c|}{ Johannsenite } & \multicolumn{2}{|c|}{ Heated johannsenite } & \multirow{2}{*}{\multicolumn{2}{|c|}{$\frac{\text { Bustamite }}{\text { Kanoiri mine }}$}} \\
\hline & & \multicolumn{4}{|c|}{ Teragochi } & & \\
\hline 1060 & s & 1062 & $\mathbf{s}$ & 1080 & $\mathbf{s}$ & 1085 & $\mathbf{s}$ \\
\hline - & - & - & - & 1020 & $\mathbf{s}$ & 1025 & $\mathbf{s}$ \\
\hline 955 & $\mathbf{s}$ & 952 & $\mathbf{s}$ & 945 & $\mathbf{s}$ & 940 & $\mathbf{s}$ \\
\hline 905 & $\mathrm{w}$ & 910 & $\mathrm{~m}$ & 905 & $\mathbf{s}$ & 905 & $\mathbf{s}$ \\
\hline 855 & $\mathbf{s}$ & 860 & $\mathbf{s}$ & - & - & - & - \\
\hline 660 & vw & - & 一 & 675 & vw & 685 & w \\
\hline
\end{tabular}

(Wave number, $\mathrm{cm}^{-1}$ )

\section{Heating product of johannsenite}

Johannsenite has a modification belonging to a high temperature form, called bustamite. This is a well known fact since johannsenite was named (SCHALLER, 1938). The johannsenite from Teragōchi, described here, was also 


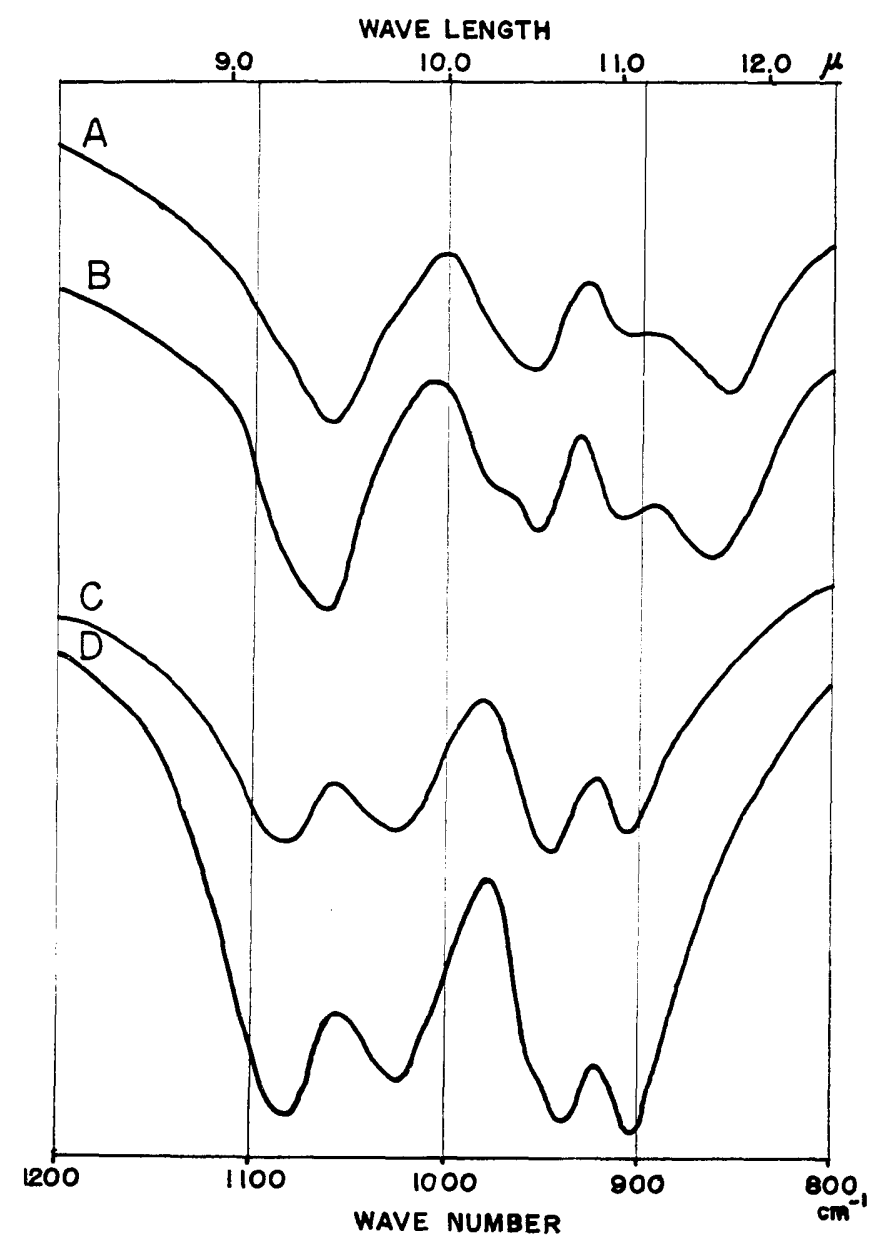

Fig. 2. Infrared absorption spectra

A: Hedenbergite from the Mitate mine, Miyazaki Pyefecture.

B: Johannsenite from Teragōchi, Okayama Prefecture.

C: Heated johannsenite, ditto.

D: Bustamite from the Kanoiri mine, Tochigi Prefecture.

easily modified into bustamite by heating at $1000^{\circ} \mathrm{C}$ for 1 hour in air. The heating product with pale grey color was examined by the $\mathrm{X}$-ray powder method and by the infrared absorption spectra in the same condition to above. The results for the blue specimen are shown in Tables 4 and 5, and in Figure 2.

The infrared absorption spectra of the heated johannsenite were compared with those of bustamite from the Kanoiri mine, Tochigi Prefecture. They agree closely with each other.

The X-ray powder data for the heated materials from Japan and from Australia (HutToN, 1956) are in good agreement in spite of the difference in iron content ( $\mathrm{FeO} 3.20$ in Japanese and $13.44 \mathrm{wt} \%$ in Australian). The contents of calcium in the original johannsenite were, $\mathrm{CaO} 19.10$ in Japanese and $20.79 \mathrm{wt} . \%$ in Australian. The structure of the heated products may be 
Table 5. X-ray powder data of heated johannsenite

\begin{tabular}{|c|c|c|c|}
\hline \multicolumn{2}{|c|}{$\begin{array}{l}\text { Johannsenite, heated in } \\
\text { air, } 1000^{\circ} \mathrm{C}, 1 \mathrm{hr} \text {. } \\
\text { Teragochi, Japan }\end{array}$} & \multicolumn{2}{|c|}{$\begin{array}{c}\text { Ferroan johannsenite, } \\
\text { heated in air, } 1070^{\circ} \mathrm{C} \text {, } \\
15.5 \text { hrs. Broken Hill, } \\
\text { Australia }\end{array}$} \\
\hline I & $\mathrm{d}(\AA)$ & I & $\mathrm{d}(\AA)$ \\
\hline $\begin{array}{l}8 \\
- \\
-\end{array}$ & $\begin{array}{l}7.52 \\
- \\
- \\
-\end{array}$ & $\begin{array}{l}1 \\
1 \\
2 \\
1 \\
1\end{array}$ & $\begin{array}{l}7.50 \\
5.20 \\
4.89 \\
4.48 \\
4.24\end{array}$ \\
\hline $\begin{array}{r}- \\
23 \\
8 \\
35 \\
12\end{array}$ & $\begin{array}{l}- \\
3.755 \\
3.566 \\
3.446 \\
3.320\end{array}$ & $\begin{array}{l}7 \\
2 \\
3 \\
2\end{array}$ & $\begin{array}{l}4.055 \\
3.76 \\
3 . \overline{44} \\
3.33\end{array}$ \\
\hline $\begin{array}{r}52 \\
49 \\
100 \\
6\end{array}$ & $\begin{array}{l}3.237 \\
2.994 \\
- \\
2.916 \\
2.734\end{array}$ & $\begin{array}{r}3 \\
5 \\
1 \\
10 \\
1\end{array}$ & $\begin{array}{l}3.25 \\
3.044 \\
2.989 \\
2.922 \\
2.751\end{array}$ \\
\hline $\begin{array}{c}8 \\
9 \\
9 \\
8 \\
20 \mathrm{~b}\end{array}$ & $\begin{array}{l}2.655 \\
2.567 \\
2.503 \\
2.477 \\
2.429\end{array}$ & $\begin{array}{l}3 \\
8 \\
1 \\
-4\end{array}$ & $\begin{array}{l}2.6885 \\
2.555 \\
2.508 \\
2 . \overline{437}\end{array}$ \\
\hline $\begin{array}{l}9 \mathrm{~b} \\
23 \\
12 \mathrm{~b} \\
8 \mathrm{~b}\end{array}$ & $\begin{array}{l}2.343 \\
2.248 \\
2.142 \\
\overline{1.976}\end{array}$ & $\begin{array}{l}3 \\
3 \\
3 \\
3 \\
1\end{array}$ & $\begin{array}{l}2.306 \\
2.251 \\
2.149 \\
2.116 \\
1.980\end{array}$ \\
\hline $\begin{array}{c}6 \mathrm{~b} \\
5 \\
15 \\
11 \\
9 \mathrm{~b}\end{array}$ & $\begin{array}{l}1.943 \\
1.898 \\
1.793 \\
1.720 \\
1.678\end{array}$ & $\begin{array}{l}1 \\
4 \\
3 \\
4\end{array}$ & $\begin{array}{l}1.9525 \\
\overline{1 .} \\
1.803 \\
1.7295 \\
1.686\end{array}$ \\
\hline
\end{tabular}

controled more effectively by the calcium atoms.

\section{Acknowledgment}

I express my sincere thanks to Professor Toyofumi Yoshimura of Kyushu University for his guidance during this work and also for his reading the manuscript. Thanks are due to Dr. Haruo SHIRozu for his reading the manuscript and much advice, to Dr. Mayumi Yoshinaga for his discussion and advice, and also to Dr. Kichinosuke Henmi and Dr. Chiharu Mitsuno of Okayama University, to Mr. Ichiro TomIokA, the mine-owner at Teragochi for their kind guides and advices in the field work. Further, this work was partly indebted to the Grant in Aid for Scientific Researches from the Department of Education of Japan. 


\section{References}

Allen, V. T. and FAHEY, J. J. (1953): Johannsenite and ferroan johannsenite at Vanadium, New Mexico. Am. Miner., 38, 883-890.

Hutton, C. O. (1956): Manganpyrosmalite, bustamite, and ferroan johannsenite from Broken Hill, New South Wales, Australia. Am. Miner., 41, 581-591.

Kuno, Hisashi and HEss, H. H. (1953): Unit cell dimensions of clinoenstatite and pigionite in relation to the common pyroxenes. Am. Jour. Sci., 251, 741-752.

Mrtsuno, Chiharu (1963): Zur Kenntnis des Oberpaläozoikums in Östlichen Chugoku, SüdwestJapan. Geol. Rept. Hiroshima Univ., no. 12, 419-443.

SchalleR, W. T. (1938): Johannsenite, a new manganese pyroxene. Am. Miner., 23, 575582.

Schiavinato, G. (1953): Johannsenite of the deposit of manganese containing silicates at Mount Civillina, near Recoaro (Vicenza, Italy). Rend. soc. miner. ital., 9, 210-218.

Yamada, Setsuo (1941): Geologic map of Japan, "Kuze" sheet. Scale 1:75,000. Geol. Surv. Japan (1951).

YAMAGUCHI, Masaru (1961): Chrome-diopsides in the Horoman and Higashi-Akaishi Peridotites, Japan. Mem. Fac. Sci., Kyushu Univ., Ser. D, Geol., 10, (2), 233-245.

Yoshimura, Toyofumi (1952): Manganese deposits of Japan. Manganese Investigation Association. $567 \mathrm{pp}$ (in Japanese). 
Hitoshi Momor

Johannsenite from Teragōchi, Okayama Prefecture

\section{Plate 6}




\section{Explanation of Plate 6}

Fig. 1-2. Polished hand specimens of johannsenites from Teragōchi, Okayama Prefecture.

1. Spherulitic green johannsenite $(J)$ cutted by quartz vein $(Q)$ with silicified aureoles and by sphalerite vein (S).

2. Fibrous green johannsenite $(\mathrm{J})$ being partially replaced by pink rhodonite (R). Lower part (Q) consists of rhodonite (grey), sphalerite (dark spots), and quartz (white).

Fig. 3-4. Microphotographs of Johannsenite-rhodonite ore. Crossed nicoles.

3. Relicts of johannsenites $(\mathrm{J})$ replaced by rhodonite $(\mathrm{R})$ and carbonitization along the columner texture of johannsenite.

4. Idiomorphic rhodonites (R) and calcites (C) replaced johannsenite (J).

Photos by H. Momol 

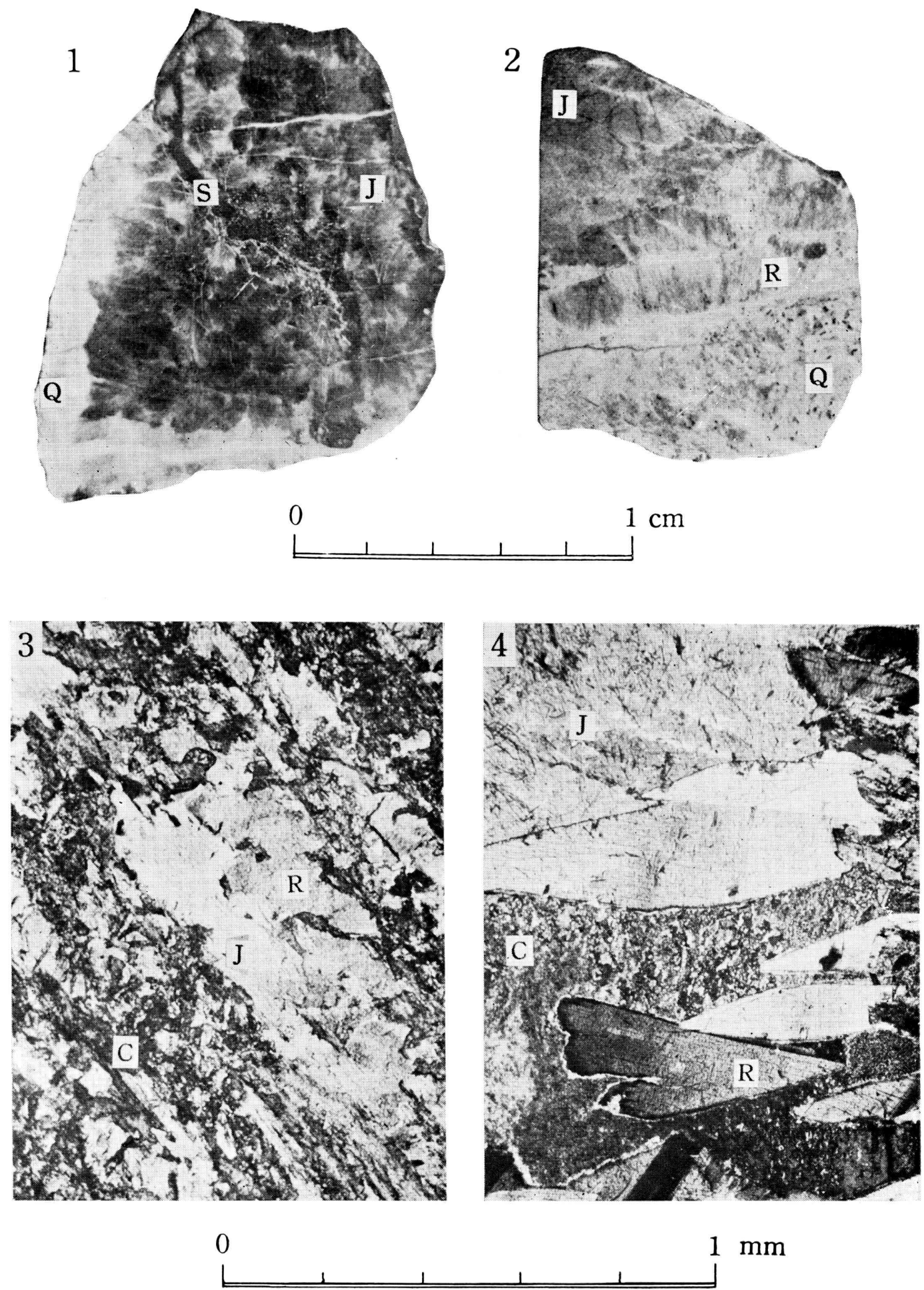

H. Moмо : Johannsenite from Teragochi, Okayama Prefecture 